\title{
“Umm you know..." Speaking or Writing?: Examining EFL Students' Writing Style in Argumentative Essays
}

\author{
Nina Setyaningsih and Anisa Larassati \\ Universitas Dian Nuswantoro, Semarang, Indonesia. \\ nina.setyaningsih@dsn.dinus.ac.id
}

\author{
ARTICLE HISTORY \\ Received : 29 December 2020 \\ Revised : 9 January 2021 \\ Accepted : 27 January 2021
}

\section{KEYWORDS \\ English as a Foreign Language (EFL) \\ Academic \\ Argumentative \\ Writing \\ Style}

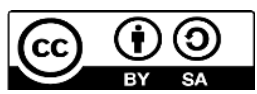

\begin{abstract}
Writing in English has always been a difficult skill to be mastered by Indonesian students. In the English Department of Universitas Dian Nuswantoro, students often face challenges in writing concerning grammatical rules and using suitable style in various text types. This research is aimed at investigating whether the students have applied formal academic style in their academic argumentative essays. The method used to analyse the data was descriptive qualitative. The findings demonstrate that there are still some significant errors made by students in their writing. Of the nine types of academic writing style errors proposed by Yakhontova (2003), there are eight types found in the data. These include contraction, addressing the reader directly, direct question, adverb in initial or final position, interjection and hesitation filler, short form of the word or slang, inappropriate negative form, and figures at the beginning of the sentence. Furthermore, the data also reveal a novel finding that there are two other kinds of error that cannot be categorised under Yakhontova's framework, namely the use of spoken form and emoticon. This research suggests that students' need to be specifically taught the differences between formal and informal styles of language in speaking and writing classes. They also need to be exposed to English academic texts more so as to be accustomed to formal or academic style.
\end{abstract}

\section{Introduction}

The first year of university life usually gives students new challenges and experience. For English as a foreign language (EFL) students, the first year also requires them to adjust with the courses which comprise not only language skills but also theories. Students who do not have basic knowledge and skills in English will face more difficulties than those who do (Wafi \& Ratnawati, 2020; Syahdan \& Putri, 2019). Although English is taught from junior high school level (even in several elementary schools and playgroups), many Indonesian students still find obstacles in using the language.

The form of language is generally broken down into speech (spoken language) and writing (written language). In addition, another form of language is sign language used by deaf communities. Simply put, regarding speech and writing, the former is spoken and heard, whereas the latter is written and read (Derin et al., 2020). The ability to use the spoken and written form of English to communicate is one of the objectives of learning English.

Writing in English is known to be one of the most difficult skills to be mastered by Indonesian students even in the university level. Writing is commonly regarded as a challenging, difficult, and frustrating aspect in teaching English as Second Language (ESL) and English as Foreign Language (EFL) students (Ado \& Alsheyab, 2019). One's competence in writing can be directly proportional to their reading skill due to how closely related these two skills are (Nation \& Macalister, 2020; Wallace \& Wray, 2021). Reading can help students learn the language and the structure of a text and then they can learn the pattern to be applied in writing. Therefore, the ability to understand texts (reading comprehension) and to write various types of texts is highly essential especially when studying in university. Students will have to accomplish tasks in most courses and this requires good reading comprehension and writing skills. Many of them will also be expected to read scientific journals and textbooks and write scientific articles and thesis. This kind of academic discourse naturally has different styles and features from other types of discourse.

Cai (2013) conducted a small-scale need analysis whose result indicates that $70 \%$ of the participants have never taken academic writing course and they found difficulties with skills that are less frequently taught. Another research was done by Birhan (2015) on the assessment of the qualities of academic writing skills in senior essays of ESL students in Ethiopia. The study found that the main problem students face in writing academic senior essays is the lack of necessary skills and using good command of English in producing academic papers sufficiently. These studies imply that writing academic texts become a significant problem for ESL students, not only in Indonesia but also in other countries.

In the English Department of Universitas Dian Nuswantoro Semarang, Indonesia, students frequently face 
various challenges in writing, ranging from grammatical rules to applying appropriate style in different text types. Furthermore, as students in the first year (first and second semester) have not had advanced knowledge of English, they often have difficulties in using certain style of language in different contexts. As a case in point, when asked to create a formal writing, they use variations commonly found in spoken language.

Considering the above issue, this research will look further into the way students of English Department of Universitas Dian Nuswantoro write texts. This research will focus on whether the students' texts comply with the style of formal academic writings.

\section{Literature Review}

Language is generally articulated into spoken and written modes. Another mode is the sign language, which is commonly used by the deaf communities. Regarding the differences between spoken and written language, Halliday (1989) identifies three aspects of speech and writing as follows:

a. Writing leaves out the prosodic and paralinguistic contributions. In contrast, speech does not show sentence or paragraph boundaries.

b. Speech and writing are used in different contexts and for different purposes. Thus, application form and office memorandum are usually in the form of written language. The meanings expressed in contexts in which writing is used are typically not translated into talk. As Halliday illustrates, we do not read aloud the regulations in the airline ticket, nor do we write down service encounters in daily life.

c. Speech and writing impose different grids of experience. Writing creates a world of things, while speech creates a world of happening.

EFL students usually have difficulties in writing academic texts. These difficulties mostly deal with vocabulary, grammar, and sentence structure. That is why, compared to L1 students, EFL students usually put more efforts to write an academic text (Wirantaka, 2016).

Different types of writing also have different characteristics. It is essential that students know how to develop a paragraph in academic writing. Students need to make sure that the language used in developing the paragraph is correct, formal, systematic, and suitable with academic nature (Wirantaka, 2016). They should arrange the sentences so as to give results in good comprehension to the readers. In the context of English formal writing, according to Jordan in Suharno (2001) the language of scientific English typically does not use styles of contractions, hesitation fillers, verb phrases or prepositional verbs and personal pronouns.
The students' academic writings must always show an engaging and appropriate academic style. Formal academic English will commonly avoid the following items (Yakhontova, 2003):

a. Contractions

The research won't be continued until appropriate funding is secured.

b. Interjections and hesitation fillers Well, we will now consider the influence of sex hormones on stress response.

c. Addressing the reader directly. You can see the data in table 3.

d. Phrasal verbs (although not always) Researchers have found out that many mental illnesses are based on molecular defects.

e. Direct questions (although not always) What can be done to improve the state of our economy?

f. Adverbs in initial or final positions

Then it will be shown how teachers can utilize this method.

g. Inappropriate negative forms. (not...any $\rightarrow$ no, not...many $\rightarrow$ few, not...much $\rightarrow$ little)

The government won't do much to support universities in the near future.

h. Short forms of the words or slang

This booklet describes the requirements and content of the university graduation exams.

i. Figures at the beginning of the sentence. 97 people visited the museum last week.

Furthermore, other stylistic issues that also need to be considered in an academic writing (Murray, 2012) such as humor, the format of the writing, and emotive language. Murray (2012) argues that attempts to add humor in an academic writing can easily backfire and eventually causing the text to sound naïve and immature. He adds that undergraduate students rarely have the ability to adopt a tone and sophistication that will go some way to ensuring that it is well received by the reader. In terms of formatting the writing, Murray (2012) suggests several rules including organising the text using headings and subheadings, justifying the text, numbering pages and figures, and avoiding casual fonts and multiple colors. It is also essential to be cautious of emotive language since in academic writing a writer needs to appear fair and objective in discussing and evaluating the ideas. Emotive language is commonly indicated by some of emotive words such as terrible, amazing, fantastic, crazy, awesome.

According to Fitzgerald in Suharno (2001) in scientific writing, comments and interpretations are expressed in an objective and personal way by using the following structure:

a. Modal adjuncts, i.e, expression of speakers' judgment about the relevance of the message (unfortunately). 
b. Modal auxiliaries (can, could, may, etc.) which reflect the author's judgement on how likely or how usual something is or is not and on what should or should not be done and lexical items in the form of adjectives expressing the author's attitude.

c. Verbs projecting the author's opinion, feeling, seeing, thinking, and saying.

The mastery of speaking and writing in ESL has been of an important issue to be discussed by teachers and researchers. Studies on language styles of both spoken and written language have also been conducted by several researchers. Sinaga \& Husein (2018) analyses the language styles used by male and female teachers in teaching English in a classroom. They found that male and female teachers mostly used formal style. The teachers also used informal, colloquial, and slang. The choices of different styles were due to several factors, such as the teachers' effort in explaining the material and the classroom condition since they had to control the classroom atmosphere.

A research conducted by Amiri \& Puteh (2017) examines errors found in the academic writing of international postgraduate students of a Malaysian public university. The researchers analysed term papers related to thesis topic written by the Iranian postgraduate students. The findings of this research demonstrate that the postgraduate students commonly commit errors that deal with sentence structure, articles, punctuation, and capitalization. The errors are influenced by the students' first language and their lack of experience in writing academic texts. Using similar framework by Corder (1967), Mohammed \& Abdalhussein (2015) conducted an grammatical error analysis of Iraqi postgraduate students. Their study indicates that the students have competence in basic rules of the target language but there is also interference from their first language.

While Sinaga \& Husein (2018) look at the use of certain language style on the teacher side, Amiri \& Puteh (2017) and Mohammed \& Abdalhussein (2015) concern on the formal writing style of students' texts emphasising on the errors made by Iranian and Iraqi postgraduate students. Meanwhile, this research was conducted to fill the gap by focusing on the style of academic argumentative essays written by undergraduate Indonesian students.

\section{Method}

The study employed a qualitative descriptive method in the data analysis. Qualitative research concerns with an inductive investigation of the data to recognize repeating themes, patterns, or concepts and then those categories are described and interpreted (Nassaji, 2015). This research is aimed at analysing essays written by students by describing how formal academic writing style is implemented in the essays.

The data of this research were taken from 28 essays written by students in the Advanced Genre Based Writing course. This course introduces students to texts that commonly use academic and formal writing in English. The essays used in this research are all categorised as argumentative text in which the students wrote about Covid-19 as the main topic. The sub-topic includes the live before and after Covid-19, online class versus offline class, and the country lockdown system.

After the essays were gathered, they were analysed by examining the elements in the essay especially in terms of words, phrases, and sentences. These elements were then classified based on whether they follow the characteristics of academic writing style. The main framework used in this research is the classification of academic writing style error by Yakhontova (2003). In analysing the data, the researchers focus more on the style rather than the grammatical error of the text.

\section{Results \& Discussion}

The results show that most of the students seem to be relatively unfamiliar with academic writing style as there are still some significant errors in their writing in the form of words, phrases, and sentences. Among nine types of academic writing style errors proposed by Yakhontova (2003), there are eight types found in the data. In addition, a closer look on the data reveals that there are also two other types of error that cannot be categorised under Yakhontova's label, namely the use of spoken form and emoticon. The numbers of each error are shown in Table 1.

Table 1. Types of Writing Style Error

\begin{tabular}{clc}
\hline No & \multicolumn{1}{c}{ Style Error Category } & Number of Error \\
\hline 1 & Contraction & 100 \\
2 & The use of spoken form & 65 \\
3 & $\begin{array}{l}\text { Addressing the reader } \\
\text { directly }\end{array}$ & 45 \\
4 & Direct Question \\
5 & $\begin{array}{l}\text { Adverb in initial or final } \\
\text { position }\end{array}$ & 15 \\
6 & $\begin{array}{l}\text { Interjection and hesitation } \\
\text { filler }\end{array}$ & 4 \\
7 & $\begin{array}{l}\text { Short form of the word or } \\
\text { slang }\end{array}$ & 2 \\
8 & $\begin{array}{l}\text { Inappropriate negative form } \\
9\end{array}$ & $\begin{array}{l}\text { Figures at the beginning of } \\
\text { the sentence }\end{array}$ \\
10 & The use of emoticon & 2 \\
\hline
\end{tabular}

Table 1 shows that contraction is the most common style error. Among all the 28 students, there are only 3 students who do not use any contraction in their texts. 
Contractions of the negative forms such as don't, doesn't, can't, aren't, isn 't, won't occur relatively often followed by other form such as they're, we'll, and it's. The examples can be seen in the following excerpts:

\section{“[...] it's getting worst in January 2020."}

Excerpt 1, data no.23

"Students don't need to be in the same physical place..."

Excerpt 2, data no.7

Interestingly, the second most common error is the use of spoken form with a total of 65 occurrences. Although Yakhontova has listed interjection and hesitation fillers, direct question, and addressing the reader directly which can also be categorised as spoken form as academic writing style error, the researchers found more types of spoken forms which cannot be listed under those three categories. Therefore, the researchers categorised the errors under the use of spoken form category as it can cover larger error types.

In the use of spoken form category, personal pronoun $I$ and the phrase I think occurs frequently. This might be because the students are required to write an argumentative text to express their opinion and believes. However, it is also known that argumentative essay pictures the writers' thought. Thus, using first person pronoun is not necessary. The students also make their writing voice weaker and personal rather than academic by using the phrase I think. Although some researchers argue that the use of firstperson pronoun, $I$ is acceptable in academic writing to show the writer stance (Hyland, 2002), this study argues that the $I$ used by the students are more spoken and informal in terms of form.

Some of the examples are shown in the following excerpts:

"I think it is not applicable in my life..."

Excerpt 3, data no. 15

"I think that's it..."

Excerpt 4, data no. 17

"I totally agree with this "lockdown"..."

Excerpt 5, data no. 22

"And I will tell how the condition after covid..."

Excerpt 6, data no. 12

In addition, some students also adopt spoken forms in their writing by using informal greetings and selfintroduction. These make the essays sound repetitive as the students have written their names, student number, and group at the beginning of their essay. Thus, selfintroduction is not necessary. Some of the examples can be found in the following excerpts:

"Hello, I will tell a little story about life before and after covid."

Excerpt 7, data no. 12

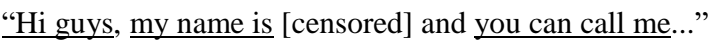

Excerpt 8, data no. 15

Not only begin the essay with greetings, some students also close the text with gratitude instead of giving concluding remarks. It makes their writings stylistically like informal speech draft instead of argumentative essay. The following excerpts show how some students give closing statement in their essay:

"[...] so it does not cause many more adverse human impacts. Thank you."

Excerpt 9, data no. 3

"Stay at home, stay healthy and stay positive for you guys. Thank you."

Excerpt 10, data no. 15

Furthermore, students tend to address the reader directly by using personal pronoun you. There are six students who use a total of 45 personal pronoun you to address the reader as seen in the excerpts below:

"Usually, you go outside not wear a masks, now you must wear it."

Excerpt 11, data no. 11

Direct questions also occur frequently for 15 times throughout the data from eight students. The examples can be seen in excerpts below:

"Nothing is different, right?"

Excerpt 12, data no. 4

"Work from home or work in the office?"

Excerpt 13, data no. 14

"You don't need to leave your home if you don't really need to."

Excerpt 14, data no. 24 
There are also 6 other types of errors with minimum occurrences. The use of adverbs in initial position occurs 6 times from 5 essays, while interjection and hesitation fillers are used 4 times by 2 students. Each of these error categories are presented in the following excerpts. Excerpt 15 displays how student place an adverb in the beginning of a sentence. Excerpt 16 indicates that the student uses interjection while excerpt 17 and 18 show that they also use hesitation fillers in their sentences as if they are talking to their reader directly. Furthermore, there is also one student who uses short form pros and cons in her essay as seen in excerpt 19 .

\footnotetext{
“Actually this virus doesn't last long when flying in the air or attached to objects."
}

Excerpt 15, data no. 22

"Oh, this topic is excludes people who are doing thesis and the others."

Excerpt 16, data no. 4

"Yeah everyone know it..."

Excerpt 17, data no. 9

"At life before pandemic everything was free umm you know..."

Excerpt 18, data no. 9

"[...] both online learning and its traditional counterpart have pros and cons."

Excerpt 19, data no. 7

Another finding that cannot be categorized under Yakhtova's categorization of error is the use of emoticon in academic writing. Although the occurrence of this emoticon is not significant in the data, in which only one student who uses one smiley emoticon, it is still an interesting finding.

"But it's okay, we hope this soon passes. :-)"

Excerpt 20, data no. 12

Since the university employed online class system during the Covid-19 pandemic, the students are required to submit the essays in a form of softcopy online. It enables them to insert other characters such as emoticon in their writings, as seen in excerpt 20, which in turn makes their writing tone unacademic.

\section{Conclusion}

The findings suggest that the students writing style is strongly influenced by spoken forms which are mostly informal, and possibly also their frequent use of social media and text messaging. Students' exposure to informal spoken style in the media, although in the form of text, may contribute to the lack of their ability to employ academic writing style. This research is expected to help both the students and the lecturer to give more attention on writing style rather than just grammatical error. It is hoped that the research can help them to pinpoint the most common error in academic writing, specifically in argumentative essay. Further research is needed to explore more types of essay such as comparison and contrast text which may result in different findings, and to look at how social media and text messaging influence students' writing style.

\section{References}

Ado, M. A. \& Alsheyab, M. O. A. (2019). Level of Knowledge Awareness and Use of Planning as Writing Strategy by EFL International Students in UUM English Intensive Course. JELTL (Journal of English Language Teaching and Linguistics)

Amiri, F., \& Puteh, M. (2017). Error analysis in academic writing: A case of international postgraduate students in Malaysia. Advances in Language and Literary Studies, 8(4), 141-145.

Birhan, Y. 2015. Assessment of the qualities of academic writing in senior essays of English graduates: The case of Dire Dawa University. International Journal of English and Literature Vol.8 (8), pp. 102-114, October 2017

Cai, L. J. (2013). Students' Perceptions of Academic Writing: A Needs Analysis of EAP in China. Language Education in Asia, 4(1), 5-22. http://dx.doi.org/10.5746/LEiA/13/V4/I1/A2/Cai

Corder, S. P. (1967). The Significance of Learners' Errors. International Review of Applied Linguistics, 5(4), 161-169.

Derin, T., Nursafira, M. S., Yudar, R. S., Gowasa, N. S., \& Hamuddin, B. (2020). Persuasive Communication: What Do Existing Literature Tells Us About Persuasive Communication Among Students?. Utamax: Journal of Ultimate Research and Trends in Education, 2(1), 12-18.

Halliday, M. A. K. (1989). Spoken and Written Language. Oxford: Oxford University Press.

Hyland, K. (2002). Authority and invisibility: authorial identity in academic writing. Journal of Pragmatics, 34, 1091-1112.

Mohammed, M. S., \& Abdalhussein, H. F. (2015). Grammatical error analysis of Iraqi postgraduate students' academic writing: The case of Iraqi students in UKM. International Journal of Education and Research, 3(6), 283-294.

Murray, N. (2012). Writing essays in English language and linguistics: Principles, tips and strategies for undergraduates. Cambridge University Press.

Nassaji, H. (2015). Qualitative and descriptive research: Data type versus data analysis. Sage Publications.

Nation, I. S., \& Macalister, J. (2020). Teaching ESL/EFL reading and writing. Routledge.

Sinaga, M., \& Husein, R. (2018, December). Teachers' Language Style with Reference to Sex Differences in Teaching English. In 3rd Annual International 
Seminar on Transformative Education and Educational Leadership (AISTEEL 2018) (pp. 566569). Atlantis Press. https://doi.org/10.2991/aisteel18.2018.123

Suharno. (2001). Language in Scientific Writing. Retrieved from http://eprints.undip.ac.id/3708/2/LANGUAGE_IN_ SCIENTIFIC_WRITING(3).pdf, retrieved 2 April 2020.

Syahdan, S., \& Putri, E. U. (2019). Applying Possessive Pronoun in Writing Sentences: Exploring Students' Ability and Problems in a Mixed Method Study. REiLA: Journal of Research and Innovation in Language, 1(3), 89-93.

Wafi, A., \& Ratnawati, R. (2020). Error Analysis on Voicing Sounds Uttered by English Department Students at State Islamic Institute of Madura. PANYONARA: Journal of English Education, 2(2), 81-96.

Wallace, M., \& Wray, A. (2021). Critical reading and writing for postgraduates. Sage Publications Limited.

Wirantaka, A. (2016). Paragraph Writing of Academic Texts in an EFL Context. Journal of Foreign Language Teaching and Learning, 1(2), 34-45.

Yakhontova, T. V. (2003). English academic writing: For students and researchers. New York: Longman. 